\title{
O IMPOSTO SOBRE TRANSFERÊNCIA IMOBILIÁRIA
}

\author{
THE REAL ESTATE TRANSFER TAX
}

\section{RESUMO}

O artigo debate o papel da tributação sobre a transferência imobiliária pelo ITBI no Brasil a luz da experiência internacional, analisando as suas principais características e desafios jurídicos. Apesar da arrecadação real ter triplicado em relação à última década, devido ao aumento das transações imobiliárias, aumento de alíquota e melhoria na administração tributária, muitos países alcançam indicadores de arrecadação superiores ao Brasil por possuírem maiores alíquotas (inclusive seletivas e progressivas, que são proibidas no Brasil), e principalmente uma base de cálculo ampliada que abrange veículos, aluguéis, ativos financeiros, entre outros atos jurídicos de registro e transferência. $O$ artigo também evidenciou que o ITBI tem sido uma fonte de receitas importante em municípios pequenos com relevante setor de agronegócios, servindo como fonte de informações do comércio de terras rurais. $\mathrm{O}$ artigo finaliza propondo uma reforma tributária que torne o imposto progressivo, que ele possa ser usado para combater a especulação imobiliária e que ele tenha sua base de cálculo ampliada para o registro e transferência de outros ativos reais.

Palavras-chave: ITBI, imposto sobre transferência imobiliária, federalismo, municípios, reforma tributária, progressividade tributária

\section{ABSTRACT}

The article discusses the role of taxation on property transfer by ITBI in Brazil in the light of international experience, analyzing its main characteristics and legal challenges. Although real tax revenues have tripled over the last decade due to increased real estate transactions, tax rate increases and improved tax administration, many countries achieve higher tax revenue indicators than Brazil because they have higher tax rates (including selective and progressive tax rates, which are prohibited in Brazil), and mainly an expanded calculation base covering vehicles, rents, financial assets, among other legal acts of registration and transfer. The article also showed that ITBI has been an important revenue source in small municipalities with a relevant agribusiness sector, serving as a source of information for rural land trade. The article concludes by proposing a tax reform that makes the tax progressive, that it can be used to combat real estate speculation and that it has its broad calculation base for the registration and transfer of other real assets.

Keywords: ITBI, real estate transfer tax, federalism, municipalities, tax reform, tax progressivity

\author{
Pedro Humberto Bruno de \\ Carvalho Júnior ${ }^{\text {a }}$ \\ ${ }^{a}$ Instituto de Pesquisa Econômica \\ Aplicada (IPEA), Rio de Janeiro, RJ, Brasil
}

DOI: $10.12957 /$ geouerj.2020.48412

Correpondência: pedro.carvalho@ipea.gov.br

Recebido em: 20 set. 2019

Revisado em: 18 out. 2019

Aceito em: $16 \mathrm{dez} .2019$ 


\section{INTRODUÇÃO E REVISÃO DA LITERATURA}

Segundo o FMI (2014) e a OCDE (2015), existem quatro tipos principais de impostos sobre a propriedade: a) impostos recorrentes (anuais) sobre a propriedade; b) impostos sobre a riqueza pessoal; c) impostos sobre espólios, heranças e doações; e d) impostos incidentes sobre alteração de direitos e/ou transferência da propriedade financeira, mobiliária ou imobiliária. Os dois primeiros tributam anualmente estoque de propriedade do contribuinte e tendem a possuir receitas relativamente estáveis, enquanto os dois últimos tributam os fluxos de transferência de propriedade (heranças e venda de ativos), possuindo arrecadação muito mais dependente do ciclo econômico. Norregaard (2013) relata que a tributação da venda de ativos seria o imposto sobre a propriedade que causa maior impacto econômico sobre a produção, não sendo aconselhado que ele tenha um peso importante em um sistema tributário de um páis. Particularmente, o autor relata que (p.15):

\footnotetext{
In recent studies, in part based on a broad review of the literature, OECD (2008 and 2010) establishes a "tax and growth ranking" with recurrent taxes on immovable property (and residential property in particular) being the least distortive tax instrument in terms of reducing long-run GDP per capita, followed by consumption taxes (and other property taxes), personal income taxes, and finally corporate income taxes as the most harmful for growth. Hence, a revenue neutral growth-oriented tax reform would involve shifting part of the revenue base from income taxes to consumption and immovable property.
}

Por outro lado, o imposto sobre a transferência imobiliária, também conhecido como "Imposto do Selo" é um dos mais antigos e tradicionais impostos existentes. Ele possui administração menos complexa, possuindo menos contribuintes que a maioria dos outros impostos, além de terem menor probabilidade de serem evadidos e inadimplidos. Além disso, o imposto possui menor custo político, visto que o contribuinte tem como contrapartida o registro e legalização da transferência imobiliária, o que é uma garantia ao seu direito sobre a propriedade.

Smolka (2013) afirma que os impostos sobre propriedade, incluindo o imposto sobre a transferência imobiliária, tende a não inflacionar significativamente o preço dos imóveis, pois os proprietários não conseguem repassá-lo completamente aos compradores devido a inflexibilidade da oferta da terra urbana e consequentemente da oferta de imóveis. $\mathrm{O}$ autor argumenta que geralmente uma majoração do imposto sobre a transferência leva a um aumento do preço dos imóveis em proporção muito menor que ao aumento do imposto.

UN-Habitat (2013) relata que o imposto sobre transferência imobiliária é uma ferramenta útil para catalogar informações do mercado imobiliário, recomendando alíquotas ao redor de $2 \%$, mas afirmando que alíquotas superiores a 5\% tem o potencial de causar distorções significativas no mercado imobiliário. Isso pode ser o caso Brasil, onde o ITBI possui alíquota ao redor de $2 \%$, não sendo observado por nenhum estudo que o imposto inibe a formalização das transações imobiliárias. Além disso, a administração tributária municipal 
pode usar os valores de compra e venda declarados nas guias do ITBI como fonte de dado para atualizar as Plantas Genéricas de Valores do IPTU. Algumas evidências empíricas corroboram essa suposição. Carvalho Junior (2017) constatou que o aumento da alíquota do ITBI de 2\% para 3\% no Município de São Paulo em 2015 (um aumento de 50\%), aumentou a arrecadação real do imposto em $20 \%$ em relação a 2014, não reduzindo o número de transações imobiliárias esperado para aquele ano.

No entanto, em países com tributação mais alta sobre a transferência imobiliária (ver exemplos na Tabela 2 e 3), o aumento das alíquotas tem o potencial de causar uma diminuição no número de transações imobiliárias. Estudo de Dachis et al. (2012) mostrou que o aumento das alíquotas e a introdução da progressividade em Toronto reduziu o número das transações imobiliárias em 15\% e o valor dos imóveis em montante igual ao aumento do imposto. Estudos de casos na Austrália (DAVIDOFF; LEIGH, 2013), França (BERÁRD; TRANNOY, 2017) e Reino Unido (BESLEY et al., 2014; BEST; KLEVEN, 2016) também constataram que o aumento e a progressividade das alíquotas reduziram o número de transações e o valor dos imóveis nesses países. Norregaard (2013) ainda relata que altas alíquotas não é uma realidade apenas em países desenvolvidos. O autor identificou alíquotas entre $12 \%$ e 15\% na Jamaica, Namíbia, Rep. Centro Africana e Senegal. Obviamente a falta de um mercado imobiliário desenvolvido e a má administração tributária impedem que tais países obtenham receitas significativas com o imposto.

Por outro lado, Aregger et al. (2013), bem como Crow et al. (2001) e Norregaard (2013), veem que impostos progressivos sobre transferência imobiliária e sobre ganhos de capital na venda de imóveis podem ser altamente positivos pois eles têm a capacidade de conter episódios de bolhas imobiliárias que trazem graves consequências econômicas para a economia real. Por exemplo, em um cenário de crescimento do preço dos imóveis em uma economia, a alíquota do imposto progressivo bem estruturado seria automaticamente majorada, inibindo a espiral inflacionária do preços dos imóveis e repartindo com a sociedade os ganhos do desenvolvimento econômico, que por outro lado, seria apropriado apenas pelos proprietários de imóveis.

\section{Experiência Internacional}

Apesar da literatura econômica apontar que os impostos incidentes sobre a transferência imobiliária têm efeitos econômicos mais deletérios que os impostos recorrentes sobre a propriedade, eles ainda são muito usados em vários países devido a sua tradição e simplicidade. Em 2012, a Comissão Europeia (2015) verificou que a Áustria, Bélgica, Croácia, Espanha, Finlândia, Holanda, Hungria, Luxemburgo, Malta e Portugal possuíam a arrecadação dos impostos sobre transferência de propriedade imobiliária e financeira iguais ou superiores aos seus impostos recorrentes sobre a propriedade. 
Levantar as arrecadações dos impostos exclusivos sobre a transferência imobiliária, (análogos ao ITBI no Brasil), é uma tarefa complexa visto que a $\operatorname{OCDE}(2017$, p.324) delimita que a subclassificação n. 4400 dos Impostos sobre a Propriedade corresponde ao: "Tax on Finantial and Capital Transactions", que compreende todas os tributos aplicados em: "issue, transfer, purchase, and sale of securities, tax on checks, and tax levied on specific legal transactions such as validation of contracts and the sale of immovable properties".

No caso do FMI (2014, p. 95), o instituto considera o imposto sobre a transferência imobiliária como um imposto indireto, classificação no 114: "Tax on Good and Services", através da subclassificação no 11414 "Taxes on Financial and Capital Transactions", que compreende todos os tributos aplicados em:

\footnotetext{
"change in ownership of property, except those classified as gifts, inheritance, or estate transactions. (...) Included are taxes on the purchase and sale of nonfinancial or financial assets (including foreign exchange or securities), taxes on checks and other forms of payment, and taxes levied on specific legal transactions, such as the validation of contracts and the sale of immovable property."
}

Logo, não se pode realizar uma comparação internacional correta da arrecadação do ITBI no Brasil com o valor das arrecadações dos códigos n 4400 da OCDE ou no 11414 do FMI, pois estas classificações são mais abrangentes e englobam a tributação da transferência financeira, como no caso da antiga CPMF do Brasil. No entanto, este estudo aprofundou a pesquisa e analisou a base de dados completa da OCDE, verificando 19 países com dados mais detalhados de sua tributação. Esses países divulgaram a arrecadação individualizada de cada imposto existente no país dentro do código no 4400 da OCDE. Pela tradução literal do próprio nome do imposto ou através de pesquisa nos websites dos Ministérios Fazendários desses países, delimitou-se os impostos cuja base de cálculo englobavam apenas transferência imobiliária, o qual é mostrado pela Tabela 1. É importante ressaltar que a tabela mostra dados da tributação que incidem exclusivamente sobre a propriedade imobiliária em 22 países, com exceção de Coréia do Sul, Austrália, Bélgica, Espanha e Itália, aonde a arrecadação do imposto delimitado também alcança contratos de aluguel, transferência de automóveis, venda de empresas e operações societárias, entre outros. Evidentemente a arrecadação nesses cinco países foi muito superior aos demais.

Tabela 1. Arrecadação dos Impostos Incidentes sobre a Transferência Imobiliária (\% do PIB). Fonte: OCDE (2019)

\begin{tabular}{|c|c|c|c|c|c|c|c|c|c|}
\hline País & 2010 & 2011 & 2012 & 2013 & 2014 & 2015 & 2016 & 2017 & $\begin{array}{l}2010-7 \\
\text { (média) }\end{array}$ \\
\hline \multicolumn{10}{|c|}{ BASE TRIBUTÁRIA ABRANGENTE } \\
\hline Coréia do Sul & 1,71 & 1,71 & 1,61 & 1,57 & 1,82 & 1,99 & 1,91 & 1,93 & 1,78 \\
\hline Austrália & 0,96 & 0,86 & 0,93 & 1,09 & 1,25 & 1,37 & 1,33 & n.d. & 1,11 \\
\hline Bélgica & 0,88 & 0,92 & 0,89 & 0,90 & 0,93 & 0,95 & 1,06 & 1,10 & 0,95 \\
\hline Espanha & 0,74 & 0,60 & 0,54 & 0,54 & 0,61 & 0,66 & 0,67 & 0,73 & 0,64 \\
\hline Itália & 0,52 & 0,51 & 0,48 & 0,61 & 0,64 & 0,58 & 0,57 & 0,53 & 0,56 \\
\hline \multicolumn{10}{|c|}{ BASE TRIBUTÁRIA RESTRITA A IMÓVEIS } \\
\hline China & 0,53 & 0,65 & 0,80 & 0,85 & 0,92 & 0,85 & 0,84 & n.d. & 0,78 \\
\hline Reino Unido & 0,39 & 0,37 & 0,40 & 0,49 & 0,60 & 0,55 & 0,62 & 0,66 & 0,51 \\
\hline
\end{tabular}




\begin{tabular}{llllllllll} 
Israel & 0,47 & 0,44 & 0,38 & 0,43 & 0,45 & 0,58 & 0,54 & 0,53 & $\mathbf{0 , 4 8}$ \\
Portugal & 0,44 & 0,40 & 0,35 & 0,31 & 0,38 & 0,43 & 0,46 & 0,55 & $\mathbf{0 , 4 2}$ \\
Alemanha & 0,21 & 0,24 & 0,27 & 0,30 & 0,32 & 0,37 & 0,39 & 0,40 & $\mathbf{0 , 3 1}$ \\
Japão & 0,29 & 0,29 & 0,30 & 0,31 & 0,29 & 0,27 & 0,27 & 0,27 & $\mathbf{0 , 2 9}$ \\
Áustria & 0,25 & 0,24 & 0,29 & 0,25 & 0,26 & 0,30 & 0,32 & 0,30 & $\mathbf{0 , 2 8}$ \\
Holanda & 0,44 & 0,30 & 0,17 & 0,17 & 0,24 & 0,26 & 0,32 & 0,37 & $\mathbf{0 , 2 8}$ \\
Hungria & 0,29 & 0,24 & 0,28 & 0,22 & 0,25 & 0,28 & 0,32 & 0,34 & $\mathbf{0 , 2 8}$ \\
Rep. Tcheca & 0,19 & 0,19 & 0,19 & 0,22 & 0,22 & 0,25 & 0,27 & 0,26 & $\mathbf{0 , 2 2}$ \\
Canadá & 0,18 & 0,19 & 0,18 & 0,19 & 0,20 & 0,25 & 0,30 & 0,31 & $\mathbf{0 , 2 3}$ \\
Rep. Dominicana & 0,20 & 0,17 & 0,16 & 0,20 & 0,18 & 0,17 & 0,17 & 0,16 & $\mathbf{0 , 1 8}$ \\
Brasil & 0,14 & 0,13 & 0,16 & 0,17 & 0,17 & 0,16 & 0,15 & 0,15 & $\mathbf{0 , 1 5}$ \\
Peru & 0,13 & 0,13 & 0,16 & 0,16 & 0,13 & 0,13 & 0,13 & 0,10 & $\mathbf{0 , 1 3}$ \\
África do Sul & 0,11 & 0,10 & 0,10 & 0,10 & 0,11 & 0,13 & 0,14 & n.d. & $\mathbf{0 , 1 1}$ \\
México & 0,10 & 0,09 & 0,09 & 0,09 & 0,10 & 0,11 & 0,11 & 0,11 & $\mathbf{0 , 1 0}$ \\
Paraguai & 0,01 & 0,02 & 0,01 & n.d. & n.d. & 0,02 & 0,02 & 0,02 & $\mathbf{0 , 0 2}$ \\
\hline
\end{tabular}

Conforme mostra a Tabela 1, as arrecadações dos impostos incidentes sobre a transferência imobiliária (e sobre outros ativos quando sua base é abrangente) são bastante díspares, variando de 1,8\% do PIB na Coréia do Sul, ao redor de 1\% do PIB na Austrália e Bélgica, 0,8\% do PIB na China, 0,6\% do PIB na Espanha e Itália, e menos de $0,2 \%$ do PIB nos países em desenvolvimento selecionados na tabela.

Observa-se que o imposto somente possui arrecadação superior a 0,6\% do PIB apenas em países em que o imposto também incide sobre outras formas transferências patrimoniais, além da transferência imobiliária. Na tabela, caso se considere os países que possuem dados apenas da tributação sobre transferência imobiliária, um benchmarking internacional de arrecadação entre 0,4\% e 0,5\% do PIB, baseado nos indicadores de Itália, Reino Unido e Portugal, poderia ser estabelecido.

A Comissão Europeia (2015) catalogou as alíquotas dos impostos sobre transferência imobiliária em 2015. O órgão constatou que metade dos países membros adotavam alíquotas inferiores a $5 \%$, no entanto os valores descritos podiam estar sujeitos a muitas discrepâncias pois as alíquotas geralmente variavam conforme o tipo de propriedade e contribuinte ou o imposto podia ter a base de cálculo (valores cadastrais) defasada. Além dos dados da Comissão Europeia, o presente estudo pesquisou fontes adicionais sobre as alíquotas incidentes sobre a transferência da propriedade imobiliária e elaborou a Tabela 2 para 40 países selecionados, a seguir.

Tabela 2. Intervalo de Alíquotas Incidentes sobre a Transferência Imobiliária e Critério de Variação Fonte: Comissão Europeia (2015), KPMG (2017), Ministérios Fazendários dos países selecionados e outras múltiplas fontes. Elaboração do autor.

\begin{tabular}{lll|lll}
\hline País & Alíquotas & Variação & País & Alíquotas & Variação \\
\hline Itália & $5 \%$ a $18 \%$ & Seletiva & Suécia & $1,5 \%$ ou 4,25\% & Seletiva \\
Coréia do Sul & $2,3 \%$ a 13,4\% & Seletiva & Hungria & $2 \%$ a 4\% & Progressiva \\
África do Sul & $0 \%$ a 13\% & Progressiva & Áustria & $3,5 \%$ & Proporcional \\
Bélgica & $10 \%$ ou 12,5\% & Regional & Tailândia & $0,5 \%$ a 3,3\% & Seletiva \\
Reino Unido & $0 \%$ a 12\% & Seletiva/Progressiva & Suíça & $0 \%$ a 3,3\% & Regional
\end{tabular}




\begin{tabular}{lll|lll} 
Espanha & $6 \%$ a $11 \%$ & Regional & Rep Tcheca & $3 \%$ & Proporcional \\
Israel & $0 \%$ a $10 \%$ & Progressiva & Brasil & $2 \%$ a $3,5 \%$ & Regional/Proporcional \\
Alemanha & $5,5 \%$ a $9,2 \%$ & Regional & Malásia & $1 \%$ a $3 \%$ & Progressiva \\
Portugal & $0 \%$ a $8 \%$ & Seletiva/Progressiva & Canadá & $0 \%$ a $3 \%$ & Regional/Progressiva \\
Grécia & $4,2 \%$ a $7,2 \%$ & Regional & Noruega & $2,5 \%$ & Proporcional \\
Índia & $3 \%$ a $7 \%$ & Regional & Uruguai & $2 \%$ & Proporcional \\
Austrália & $1,2 \%$ a $7 \%$ & Seletiva/Progressiva & México & $2 \%$ & Proporcional \\
França & $5,1 \%$ a $6,4 \%$ & Regional & Polônia & $2 \%$ & Proporcional \\
Japão & $2,4 \%$ a $6 \%$ & Seletiva & Colômbia & $1,5 \%$ & Proporcional \\
Holanda & $2 \%$ ou $6 \%$ & Seletiva & Chile & $1,2 \%$ & Proporcional \\
Irlanda & $1 \%$ ou $6 \%$ & Seletiva/Progressiva & Dinamarca & $0,6 \%$ & Proporcional \\
Indonésia & $5 \%$ & Vietnã & $0,5 \%$ & Proporcional \\
Turquia & $5 \%$ & Argentina & $0 \%$ & não existe \\
China & $3 \%$ a $5 \%$ & Proporcional & Rússia & $0 \%$ & não existe \\
Estados & $0 \%$ a $5 \%$ & Regional & Nova Zelândia & $0 \%$ & não existe \\
Unidos & & & & \\
\hline
\end{tabular}

Segundo a Tabela 2, Itália, Coréia do Sul, África do Sul, Bélgica, Reino Unido e Espanha apresentaram as maiores alíquotas marginais (ou seletivas) sobre a transferência imobiliária, muito embora na Itália a base de cálculo do imposto seja um valor cadastral defasado no lugar do valor transacionado ou de mercado.

África do Sul, Reino Unido, Israel, Portugal, Austrália, Irlanda, Hungria, Malásia e Canadá apresentam alíquotas progressivas conforme o valor da transferência imobiliária, embora em Portugal e na Irlanda a progressividade só seja aplicada para imóveis residenciais e no Canadá cada província possui ampla autonomia na legislação do imposto, podendo inclusive adotá-lo ou não. Em Israel, as alíquotas majoradas de 8\% e 10\% são aplicadas apenas a estrangeiros.

Os critérios de variação das alíquotas seletivas são diversos. Na Coréia do Sul elas variam regionalmente e também por uso (residencial ou comercial) e nível de luxuosidade do imóvel. Na Suécia as alíquotas variam conforme os contribuintes (pessoas ou empresas) e na Holanda, Irlanda e Japão pelo uso de imóvel (residencial ou comercial).

Na Grécia, Índia, Alemanha, França, China, Estados Unidos, Suíça e Brasil as alíquotas são estabelecidas regionalmente (pelos municípios ou governos regionais) estando entre $0 \%$ a $7 \%$. Na China o governo central estabelece um intervalo entre 3\% e 5\% e no Brasil as alíquotas devem ser sempre proporcionais. Na Grécia, o governo central estabelece uma alíquota de $4,2 \%$, mas os governos locais podem cobrar uma alíquota adicional de até $3 \%$.

Por outro lado, na Indonésia, Turquia, Áustria, Rep. Tcheca, Japão, Suíça, Noruega, Polônia, Uruguai, México, Colômbia, Chile, Dinamarca e Vietnã as alíquotas são proporcionais e definidas nacionalmente, estando entre 0,5\% e 5\%. A Dinamarca possui alíquota de apenas 0,6\%, a menor entre os países da OCDE. Essa baixa tributação, porém, é altamente compensada pela arrecadação do imposto imobiliário, que atingiu 1,4\% do PIB dinamarquês em 2015. A Argentina possuía até 2017 um Imposto sobre a Transferência Imobiliária com 
alíquota nacional de 1,5\%, mas que foi substituído por um Imposto sobre Ganhos de Capital de 15\%. Rússia e Nova Zelândia também não tributam a transferência imobiliária.

Resumidamente, dos 40 países selecionados, em 9 existe um sistema progressivo, em 10 as alíquotas são definidas pelos governos locais, em 6 elas são apenas seletivas conforme tipo ou uso do imóvel, em 14 elas são proporcionais e definidas nacionalmente e em 3 países não existe tributação ad valorem sobre a transferência imobiliária.

Após a análise global da tributação da transferência imobiliária ao redor do mundo, as próximas subseções abordarão os principais detalhes do imposto em 14 países selecionados: Itália, Portugal, Espanha, França, Bélgica, Alemanha, Suíça, Reino Unido, Austrália, Canadá, Estados Unidos, África do Sul, China e Coréia do Sul.

Itália

Na Itália, a transferência imobiliária está sujeita a três principais impostos: dois impostos de registro (Imposta di Registro e Imposta Ipotecaria) e um imposto cadastral (Imposta Catastale), além do IVA (Imposto sobre Valor Adicionado) de $4 \%$ aplicado sobre a compra de imóveis residenciais novos e 22\% para imóveis comerciais ou considerados de luxo. A alíquota agregada do Imposta di Registro, Ipotecaria e Catastale é de $5 \%$ (primeira residência), 12\% (comércio, terrenos urbanos e demais residências) e 18\% (terrenos rurais). A base de cálculo é o valor cadastral que é muito defasado com relação ao mercado, logo a tributação efetiva da transferência imobiliária é de fato menor que a alíquota legal.

O Imposta di Registro é o mais importante dos três impostos sobre transferências de capital em termos de arrecadação e também incide sobre a transferência de automóveis, aluguéis e operações societárias. A alíquota do primeiro imóvel residencial é de $2 \%$, e nos demais casos de $9 \%$. As alíquotas para os demais fatos geradores do imposto são: $2 \%$ para contratos de aluguéis, $3 \%$ para transferência ou locação de automóveis e $3 \%$ para venda ou aluguel de empresas.

Espanha

Na Espanha, o Impuesto sobre Transmisiones Patrimoniales y Actos Jurídicos Documentados (ITP) abrange além da transferência imobiliária, a transferência de automóveis, contratos de aluguel e operações societárias. A alíquota sobre operações societárias é nacionalmente definida em 1\%. No caso das operações com ativos reais (imóveis e automóveis) as alíquotas podem ser definidas regionalmente. De acordo com o 
Real Decreto Legislativo 1 de 1993, os contratos de aluguel são tributados pelo somatório de todos os aluguéis previstos no período do contrato.

O ITP possui alíquotas regionais que variam entre 6\% e 11\%. Por exemplo, a alíquota é de 6\% em Madrid, de 10\% na Galícia e Comunidade Valenciana e progressiva até 11\% na Catalunha. No caso de imóveis novos é aplicado somente um IVA, cuja alíquotas regionais se situam entre $10 \%$ e $12 \%$ para residências e $21 \%$ para imóveis comerciais. Na Catalunha, os demais atos do ITP são tributados da seguinte maneira: 5\% para automóveis e 0,5\% para aluguéis.

\section{Portugal}

Em 2004, o “Imposto Municipal sobre as Transmissões Onerosas de Imóveis" substituiu o antigo "Imposto Municipal de Sisa (Serviço de Impostos de Sua Alteza)". O novo imposto incide sobre transferências de propriedades urbanas e rurais e suas alíquotas são estabelecidas nacionalmente, sendo seletivas e progressivas. Para imóveis residenciais urbanos até o limite de 574.323 euros é aplicada uma tabela progressiva com alíquotas entre $2 \%$ e $8 \%$, aplicando-se, porém, uma alíquota proporcional de $6 \%$ para imóveis com valores superiores. Para imóveis comerciais e rurais as alíquotas são proporcionais com valores de 6,5\% e 5\%, respectivamente (REPÚBLICA PORTUGUESA, 2017).

França

Na França, os imóveis novos, em construção ou com até 5 anos de construção são sujeitos ao IVA de $20 \%$ e um imposto de transferência imobiliária de $0,7 \%$. No caso de imóveis antigos é aplicado o Droit Comum que varia de 5,1\% a 5,8\%, exceto para certos imóveis comerciais em Paris, cuja alíquota foi aumentada para 6,4\% em 2016 (DLA PIPER, 2017).

\section{Bélgica}

Na Bélgica, o Imposto de Registro (Droits d'enregistrement), de competência regional, é o principal imposto aplicado sobre a transferência imobiliária. A sua arrecadação equivaleu em média a 0,9\% do PIB belga entre 2010 e 2015 e 2\% da arrecadação tributária total. Apesar da transferência de imóveis ser a sua principal fonte de arrecadação, a base de cálculo do imposto é bastante abrangente, englobando cinco atos:

a) Todos os atos graváveis dos notários e oficiais de justiça;

b) Escrituras e declarações de mudança de propriedade ou usufruto de bens imobiliários; 
c) Venda de ativos mobiliários e bens móveis;

d) Atos relativos a locação e arrendamento de propriedades (exceto residências);

e) Atos relativos a aporte de bens e ativos de sociedades anônimas.

Na transferência imobiliária, a alíquota básica do imposto é de 12,5\% em Bruxelas e na Valônia e de 10\% em Flandres. Na compra do primeiro imóvel, há uma redução do seu valor cadastral em 60.000 euros se o proprietário morar no imóvel por no mínimo 5 anos. Com exceção de Bruxelas, o imposto é reduzido em $50 \%$ na compra do primeiro imóvel caso tenha valor estimado de aluguel inferior a 745 euros (ou até 1.045 euros no caso de contribuintes com filhos) (Fisconetplus, 2017).

Na transmissão de bens móveis (automóveis) a alíquota é nacionalmente estabelecida em 5\%, para hipotecas em 1\% e para aluguéis e arrendamentos (exceto o aluguel residencial em que o registro é gratuito) é aplicada uma alíquota de $0,2 \%$ sobre o somatório de todos os aluguéis e encargos do contrato, valor devido tanto pelo locador quanto pelo locatário.

\section{Alemanha}

O imposto de transferência imobiliária é cobrado em nível estadual na Alemanha. A alíquota padrão é de 5\%, mas ela pode ser 3,5\% na Bavária e Saxônia, 4,5\% em Hamburgo, 5,5\% em Saarland, 6\% em Berlin e Hesse e 6,5\% em Schleswig-Holstein. O comprador do imóvel ainda está sujeito a taxas notariais e de registro que possuem alíquotas agregadas e progressivas entre $2 \%$ e 2,7\%. No final, a tributação total sobre a compra de uma propriedade pode variar de 5,5\% a 9,2\%. Propriedades novas estão isentas do imposto de transferência imobiliárias, mas sujeitas a um IVA de 19\%, além das taxas notoriais e de registro (PWC, 2016; GPG, 2017).

Suíça

A Suíça apresenta um mercado imobiliário altamente regulamentado e consequentemente o número de vendas de propriedades é baixo, predominando o mercado de aluguel. Com isso o imposto de transferência imobiliária tem arrecadado apenas 0,01\% do PIB do país. Cada cantão pode decidir aplicar o imposto ou não, e a alíquota varia entre 0,4\% a 3,3\%. Por exemplo, o Cantão de Zurique não tributa a transferência imobiliária, enquanto em Lausanne a alíquota é de 2,2\% e em Genebra é de 3\% (KPMG, 2016). 
Apesar da Suíça também possuir uma tributação sobre a propriedade imobiliária muito pequena $(0,16 \%$ do PIB em 2015), tal fato é largamente compensado pelo imposto sobre a riqueza pessoal que arrecadou 1,2\% do PIB suíço em 2015 (CARVALHO JUNIOR; PASSOS, 2017).

\section{Reino Unido}

No Reino Unido, o Stamp Duty Land Tax possui um sistema de alíquotas progressivas. O limite de isenção do imposto é de 125.000 libras para propriedades residenciais (300.000 libras para o primeiro imóvel) e 150.000 libras para propriedades comerciais. No caso do primeiro imóvel, se o valor estiver entre 300.000 e 500.000 libras, a alíquota aplicada é de $5 \%$, e caso seja superior ela varia progressivamente de $5 \%$ a $12 \%$ (critério também válido na compra do segundo imóvel). No caso de imóveis comerciais a alíquota é de $2 \%$ para valores entre 125.000 e 250.000 libras e de 5\% para valores superiores. Imóveis novos ainda são sujeitos a um adicional de 1\% a 3\% (REINO UNIDO DA GRÃ-BRETANHA E IRLANDA DO NORTE, 2017).

\section{Austrália}

Na Austrália, o Stamp Duty é de competência dos Estados e sua base de cálculo abrange: "motor vehicle registration and transfers, insurance policies, leases and mortgages, hire purchase agreements, and transfers of property (such as businesses, real estate or certain shares)." (COMUNIDADE DA AUSTRÁLIA, 2016). As alíquotas são definidas por cada estado e são em geral progressivas e seletivas por tipo de transferência. No caso da transferência imobiliária, as alíquotas progressivas estaduais podem variar entre 1,2\% e $7 \%$.

\section{Canadá}

No Canadá o imposto sobre a transferência imobiliária é legislado por cada província, embora ele não seja aplicado nas Províncias de Alberta e Saskatchewan. Nas províncias de Colúmbia Britânia, Quebec e Ontário os sistemas de alíquotas progressivas são parecidos e variam de 0,5\% a 3\% (RENX, 2015). Em 2017, uma alíquota de $15 \%$ foi introduzida em Toronto na compra de imóveis residenciais por estrangeiros não residentes, empresas estrangeiras e trusts, como forma de evitar a especulação imobiliária.

\section{Estados Unidos}

Nos Estados Unidos as alíquotas do Real Estate Transfer Tax variam de acordo com cada estado, mas em geral são menores que 1\%. No Alaska, Idaho, Indiana, Louisiana, Mississipi, Missouri, Montana, Novo México, Dakota do Norte, Texas, Utah e Wyoming o imposto não é cobrado. No Alabama, Califórnia, Colorado, 
Geórgia, Illinois, Kansas, Kentucky, Dakota do Sul e Oregon a alíquota é igual ou menor que 0,1\%. No entanto, na Cidade de Nova York a alíquota é de 2,6\%, em Delaware de 3\% e em Maryland de 5\% para terras agrícolas (NCSL, 2016 apud Lincoln Institute of Land Policy).

\section{África do Sul}

Desde 1974 a África do Sul tem um sistema de alíquotas progressivas aplicado sobre a transferência da propriedade imobiliária de competência do governo central. A partir de 2017, o Transfer Duty Tax possui uma tabela progressiva que varia de $0 \%$ para transferências menores que aproximadamente 70.000 dólares e $13 \%$ para transferências superiores a aproximadamente 800.000 dólares (SARS, 2017). Propriedade novas, por outro lado, são isentas do imposto, mas sujeitas a um IVA de 14\%. Segundo a OCDE (2017), a tributação da transferência imobiliária tem representado entre 0,15\% e 0,2\% do PIB sul-africano (nível similar ao Brasil) mesmo num cenário de maiores alíquotas. Tal fato precisaria ser melhor investigado e um dos motivos poderia ser o elevado limite de isenção ou a isenção para propriedades novas (porém, sujeitas ao IVA), a calibragem das alíquotas, problemas na administração tributária, e/ou de evasão como subdeclaração do valor das transações.

China

Na China teoricamente não existe propriedade privada da terra, mas o governo concede certificados de direito de uso que podem ser transmitidos. De acordo com o Shanda e Daoshu (2003), existem sete impostos locais sobre a propriedade. Apesar do país não possuir nenhum imposto recorrente sobre o usuário de propriedades residenciais (exceto em um projeto piloto em Shangay), os detentores de direitos de uso residencial antes de 2007 podem estar sujeitos a uma taxa de aluguel da terra estatal conforme o tamanho do imóvel. Os detentores de direitos de uso de imóveis comerciais estão sujeitos anualmente ao Real Estate Tax de 1,2\% sobre o valor de aquisição do imóvel e os imóveis alugados de qualquer uso (residencial ou comercial) estão sujeitos a um imposto local de $18 \%$ sobre o valor do aluguel (MAN, 2012).

Para propriedades novas, existe um IVA cobrado sobre os compradores e um Business Tax cobrado sobre os vendedores, ambos com alíquota de 5\%. Além disso, todos os contribuintes do IVA e do Business Tax são obrigados a pagar o City Maintenance and Construction Tax, cuja alíquota varia de 1\% (áreas rurais), 5\% (vilas) e 7\% (áreas urbanas). No total, a compra de um imóvel novo em área urbana pode estar sujeita a uma tributação total de $14 \%$ devida pelos compradores (incluindo o imposto de transferência imobiliária), e $12 \%$ pelos vendedores (JLL, 2017). 
A transferência imobiliária está sujeita ao Deed Tax e ao Land Appretiation Tax, que corresponderam a 9,3\% das receitas tributárias dos governos locais ou 0,75\% do PIB chinês em 2009 (MAN, 2012). O Land Appretiation Tax tributa o ganho de capital resultante da mudança de uso ou usuário do solo urbano, possuindo alíquotas progressivas que variam de 30\% a 60\%. O imposto está isento quando o lucro resultante da operação for inferior a $20 \%$. No entanto, a principal fonte de receitas dos governos locais chineses é o Deed Tax, que incide sobre a transferência de usuário por venda ou doação através de uma alíquota delimitada nacionalmente entre 3\% e 5\%, mas fixada por cada administração regional. Famílias compradoras do primeiro imóvel são contempladas por uma alíquota reduzida entre $1 \%$ e $2 \%$. Há ainda taxa de selo e outra de registro cartorial, cuja alíquota agregada se situa entre 0,15\% e 0,35\% (JLL, 2017).

\section{Coréia do Sul}

Na Coréia do Sul, o Aquisition Tax e Registration Tax são impostos locais (mas que também são cobrados pelo governo central sobre certos ativos) que tributam o registro, a aquisição e a transferência de diversos tipos de propriedade, incluindo imóveis, meios de transporte, máquinas de construção, "trusts", minas e empresas (LEE; KIM, 2007).

Em geral, o Aquisition Tax e Registration Tax sobre a transferência imobiliária possui alíquota padrão de $2 \%$ e $0,24 \%$, respectivamente, resultando numa tributação agregada de $2,24 \%$. No entanto, a alíquota do Aquisition Tax para imóveis comerciais é de 6,6\% e para imóveis residenciais considerados luxuosos e/ou localizados em grandes cidades pode ser de até $11 \%$ como forma de conter a especulação imobiliária (DTTL, 2016; LEE; KIM, 2007). O registro ou a transferência de automóveis é tributado pelo Aquisition Tax em $2 \%$ (sendo isento para automóveis de até 1.000 cilindradas) e pelo Registration Tax em 6\%, resultando numa tributação agregada por ambos impostos em $8 \%$ sobre automóveis.

\section{O ITBI no Brasil}

Após a resenha teórica e uma descrição do imposto sobre a transferência imobiliária em alguns países, esta seção analisará o Imposto de Transmissão de Bens Imóveis (ITBI) no Brasil. Ela é dividida em 6 partes: histórico do imposto no Brasil, questões jurídicas recentes, base de cálculo, alíquotas, arrecadação, e um debate sobre o ITBI rural.

\section{Breve Histórico}


Devido a necessidade do aumento de impostos para suprir as necessidades da vinda da família real portuguesa ao Brasil, em 1809, criaram-se vários tributos imobiliários, como a décima predial aplicada anualmente sobre o valor de aluguel dos imóveis, e um tributo denominado "Imposto de Sisa (Serviço de Imóveis de Sua Alteza)" aplicado sobre a transferência imobiliária, com alíquota de 10\% (posteriormente reduzida para 6\%) (HARADA, 2000; SILVA, 2010).

O artigo 9o da Constituição de 1891 estabeleceu a competência exclusiva dos Estados em tributar as transmissões de propriedades imobiliárias. No entanto, o artigo 8o da Constituição de 1934, criou dois impostos estaduais sobre transferência patrimonial, um exclusivo sobre a transmissão da propriedade imobiliária inter vivos (ITBI) e outro sobre a transmissão de qualquer propriedade por causa mortis (ITCM). As Constituições de 1937 e 1946 mantiveram essa mesma estrutura, porém a Emenda no 5 de 1961 alterou a Constituição de 1946 e transferiu o ITBI para a competência municipal (ANTUNES, 2012).

No período ditatorial, a Emenda Constitucional no 18 de 1965, alterou a Constituição de 1946 e fundiu novamente o ITBI e ITCM nomeando-o "Imposto sobre a Transmissão de Bens Imóveis e de Direitos a eles Relativos", de competência estadual, que passou a englobar tanto a transferência imobiliária por ato oneroso (venda) e por causa mortis (heranças). A reforma isentou a tributação sobre heranças de outros tipos de propriedade como ativos financeiros e automóveis, por exemplo. A mesma emenda determinou que o Senado Federal estabeleceria a alíquota máxima do imposto, mas na ausência de normativa do Senado, o Ato Complementar 27 de 1966 fixou que a alíquota seria de 0,5\% para as transmissões relativas ao Sistema Financeiro de Habitação, de 1\% para transmissões por ato oneroso, e de $2 \%$ para transmissões por heranças ou doações. Por fim, o ITBI ainda passou a ser regulamentado pelos artigos 35 a 39 do Código Tributário Nacional (Lei 5.172 de 1966), sendo que o artigo 24 da Constituição de 1967 apenas confirmou todas essas alterações que foram introduzidas ao ITBI.

Com a Constituição de 1988, o Imposto sobre Transferência Imobiliária foi cindido novamente, criandose o ITBI (Imposto Sobre a Transmissão de Bens Imóveis por Ato Oneroso ou Cessão de Direitos) de competência municipal e o ITCM (Imposto de Transmissão Causa Mortis e Doação de Quaisquer Bens ou Direito). A Constituição de 1988 não restringiu as alíquotas do ITBI, tendo os municípios ampla autonomia para fixá-las. No caso do ITCM, o constituinte estabeleceu que o Senado Federal deveria estabelecer a sua alíquota máxima, o qual foi fixada em 8\% pela Resolução do Senado Federal no 9 de 1992. A resolução também permitiu a progressividade das alíquotas. 


\section{Questões Jurídicas Recentes}

As principais questões jurídicas recentes relativas ao ITBI e enfrentadas por muitos municípios brasileiros envolvem o sistema de fixação das alíquotas e a delimitação da base de cálculo. Na realidade, a autonomia municipal para fixar as alíquotas do ITBI é parcial porque o município não tem autonomia, por exemplo, para fazer uma política tributária progressiva. A Súmula do STF no 656 de 2011 estabelece que: “É inconstitucional a lei que estabelece alíquotas progressivas para o imposto de transmissão inter vivos de bens imóveis - ITBI com base no valor venal do imóvel".

A justificativa para a Súmula é que o ITBI seria um imposto real, sendo necessário uma permissão constitucional para sua progressividade, conforme ocorreu com o IPTU através da Emenda Constitucional no 29 de 2000. Por exemplo, a Lei Municipal de São Paulo no 11.154 de 1991 originalmente previa um ITBI progressivo entre $2 \%$ e $6 \%$, o que fora declarado inconstitucional e posteriormente alterado para uma alíquota proporcional de $2 \%$ em 2000. No entanto, em 2013, o STF decidiu que alíquotas progressivas para o ITCM seriam legais mesmo sem previsão constitucional (seguindo o previsto pela Resolução do Senado Federal no 9 de 1992). Isso ocorreu no julgamento do Recurso Extraordinário no 562.045/RS.

A base de cálculo do ITBI é o valor venal declarado da transação imobiliária, mas a declaração do contribuinte sempre deve ser pautada em valores mínimos como forma de se evitar a evasão do ITBI e do Imposto de Renda sobre Ganhos de Capital, que pode ocorrer através da subdeclaração do valor transacionado. A disputa jurídica entre contribuintes e prefeituras tem ocorrido no modo em que se fixa esse piso mínimo, que costuma ser baseado em dois critérios: a) pelo valor venal do IPTU, que possui mecanismos definidos em lei municipal, mas com valores geralmente defasados devido à falta de atualização das Plantas de Valores; ou b) pelo valor estimado de ofício pelo fisco municipal através de pesquisas de mercado. Em 2009, o Superior Tribunal de Justiça (STJ), através da negação do Agravo Regimental no 1.102.905/SP, e também em 2013, através do julgamento do Recurso Especial no 1.199.964/SP, estabeleceu jurisprudência de que a base de cálculo do ITBI é o valor transacionado de fato, sendo permitido que os municípios elaborem mapas de valores de referência específicos para o ITBI.

\section{Base de Cálculo}

Como debatido na seção anterior, tradicionalmente a base de cálculo do ITBI consistia no valor da transação imobiliária declarado pelo contribuinte, porém não podendo ser inferior ao valor venal do IPTU. Como os valores venais do IPTU podem ser muito defasados por falta de atualização das Plantas de Valores, representando em alguns municípios entre $10 \%$ e 30\% dos valores de mercado e considerando entre 2009 e 2015 um cenário crescente valorização imobiliária, muitos municípios passaram a criar sistemas de valores de referência para ITBI baseados em pesquisas de mercado. Os valores de referência servem para confrontar com 
os valores declarados pelos contribuintes, servindo de valor mínimo para lançamento do ITBI, inclusive o ITBI rural.

Os principais críticos do modelo argumentam que que tais valores de referência são lançados de ofício e geralmente estão apenas dentro dos sistemas informatizados das Secretarias de Fazenda, não sendo explicitados em nenhuma legislação municipal e, portanto, pouco transparentes. As prefeituras argumentam que o mercado imobiliário é dinâmico e os valores de referência são atualizados em uma base mensal. Caso não concordem, os contribuintes podem solicitar, sem custo, uma avaliação imobiliária individualizada executada por engenheiro avaliador municipal.

As maiores cidades, como por exemplo, São Paulo, Rio de Janeiro, Salvador, Distrito Federal, Belo Horizonte, Curitiba e Porto Alegre já possuem valores de referência específicos para o ITBI, embora a maioria dos municípios brasileiros ainda careça do uso desse instrumento, tendo o valor venal do IPTU ou o valor base do ITR como pisos mínimos aos valores declarados pelos contribuintes.

No Rio de Janeiro, por volta de 2000, a Secretaria Municipal de Fazenda (Sefaz) passou a adotar um sistema baseado em preços de mercado para o lançamento do ITBI. Caso o contribuinte não concorde com o valor arbitrado, ele tem até 30 dias para impugnar o valor venal, cujo processo leva em média 15 dias para ser julgado. Nesse caso o contribuinte deve se dirigir pessoalmente à sede da Sefaz e protocolar, entre outros documentos e informações, fotos da fachada do imóvel e anúncios de imóveis similares em jornais. Este processo tem sido pouco usado, devido as poucas chances de revisão e da necessidade que os contribuintes têm em pactuar rapidamente a transação imobiliária.

Em Porto Alegre, a diferenciação do valor venal do IPTU e do ITBI ocorreu em 2005, através da Lei Complementar no 536. No Distrito Federal, a instituição de um sistema avaliatório próprio para o ITBI foi instituído pelo artigo 6o da Lei Distrital 3.830 de 2006. São Paulo, através da Lei Municipal 14.256 de 2006 e Salvador, através da Lei Municipal 8.421 de 2013, instituíram um modelo similar de cobrança do ITBI. Ambos municípios criaram o "Valor Venal Atualizado" do imóvel para a cobrança do ITBI, cujo valor é diferente do valor venal do IPTU. Da mesma maneira que no Rio de Janeiro, caso não concorde com o valor de referência, o contribuinte pode requisitar gratuitamente uma avaliação imobiliária individualizada ao fisco municipal.

\section{As Alíquotas}

Conforme descrito na Seção 3.2, os municípios brasileiros têm autonomia para estabelecer o valor da alíquota proporcional do ITBI, só havendo impedimento legal para aplicação da progressividade, conforme a Súmula no 656 do STF. A grande maioria dos municípios brasileiros adota uma alíquota proporcional de $2 \%$ 
aplicada à transferência de imóveis urbanos e rurais. No entanto há uma tendência recente, principalmente nas grandes cidades, e por motivos fiscais, da majoração da alíquota do ITBI.

Como exemplos, têm-se, a partir de 2012, o aumento de alíquota do ITBI de 2\% para 3\% em dez capitais estaduais: Maceió (em 2012), Natal (em 2013), Belo Horizonte, Curitiba, Florianópolis, Fortaleza e Recife (em 2014), São Paulo (em 2015), Brasília (em 2016) e Rio de Janeiro (em 2018). Em outros municípios, por motivos políticos, houve o retorno para a alíquota original de 2\%. É o caso de Goiânia (em 2015) e Florianópolis (em 2017). Por outro lado, Salvador, João Pessoa e Porto Alegre adotam a alíquota majorada do ITBI de $3 \%$ desde 1998, 2007 e 2009, respectivamente, enquanto Goiânia possuiu alíquota de 3,5\% entre os anos de 1990 e 2014. Por outro lado, Manaus, Belém, Porto Velho, Palmas, São Luís, Teresina, Aracaju, Vitória, Juiz de Fora, Uberlândia, Niterói, São Gonçalo, Campinas, Guarulhos, Santos, Santo André, São Bernardo do Campo, São José dos Campos, Campo Grande e Cuiabá são exemplos de grandes cidades que nunca adotaram uma alíquota do ITBI superior a $2 \%$.

Apesar de não haver mais nenhuma obrigação legal dos municípios aplicarem a alíquota de 0,5\% para imóveis financiados pelo SFH, como era a regra antes da Constituição de 1988, a maioria estabelece alíquotas de $0,5 \%$ ou $1 \%$ para o primeiro imóvel financiado pelo SFH até certo valor, segundo o critério de cada município. Fortaleza ainda prevê uma redução do ITBI de 3\% para 2\% se o imposto for pago dentro do prazo estabelecido em sua legislação. Conforme mencionado na Seção 1, estudos internacionais destacam que uma tributação muito alta sobre a transferência imobiliária, por exemplo superior a 5\%, pode impactar negativamente o mercado imobiliário e reduzir o registro das transações. Tal fato não foi verificado no Brasil, pois o aumento da alíquota de 2\% para 3\% ocorrido nas oito capitais estaduais citadas entre 2012 e 2016 , ao contrário, aumentou a arrecadação esperada do ITBI. Em 2011, o ITBI representou 3,0\% das receitas correntes dessas capitais, percentual que aumentou para 3,4\% em 2015, mesmo com um cenário macroeconômico de queda do PIB, de redução do financiamento habitacional e consequentemente das transações imobiliárias.

\section{Arrecadação}

A arrecadação do ITBI entre 1998 e 2006 se situou ao redor de 0,10\% do PIB brasileiro, mas o indicador médio aumentou para 0,16\% do PIB a partir de 2010 devido principalmente ao aumento do:

a) valor dos imóveis;

b) número de transações imobiliárias;

c) volume de financiamento habitacional que demanda o registro das transações;

d) valor da alíquota de $2 \%$ para $3 \%$ por algumas cidades; e 
e) grau de eficiência na administração tributária municipal, como a fixação de valores de referência do ITBI.

Desde 2008, a arrecadação nacional do ITBI tem se situado entre $30 \%$ e $40 \%$ da arrecadação nacional do IPTU. Tal fato é curioso, pois a base de cálculo potencial do IPTU, o estoque de todos os imóveis urbanos, é muito maior que a base de cálculo do ITBI, as transações imobiliárias legalizadas ocorridas em um determinado ano. Esse fato tem ocorrido devido a cinco principais motivos:

a) As alíquotas do ITBI são geralmente maiores que as do IPTU;

b) O ITBI também incide sobre imóveis rurais;

c) As Plantas de Valores do IPTU costumam ser muito defasadas em relação ao mercado;

d) É muito mais comum a concessão de isenções do IPTU; e

e) A inadimplência do IPTU é muito elevada na maioria dos municípios brasileiros.

De fato, houve um crescimento de $80 \%$ do indicador de arrecadação do ITBI pelo PIB, passando de 0,09\% entre 2002 e 2006, para 0,16\% entre 2010 e 2018. Já o do IPTU se manteve estável entre 2002 e 2014 representando em média 0,44\% do PIB brasileiro. No entanto, o indicador aumentou para 0,55\% entre 2016 e 2018. Isso provavelmente ocorreu devido a melhora na administração tributária nas grandes cidades como o recadastramento e atualização da Planta Genérica de Valores, auxiliado pela queda real do PIB brasileiro, pois arrecadação do IPTU é menos impactada pela variação do ciclo econômico. Em 2018, o IPTU representou 0,63\% do PIB brasileiro, um aumento de 43\% em relação a 2012. Tendência similar ocorreu com os indicadores de arrecadação per capita. Entre 2002 e 2006, o ITBI per capita era de R\$ 23 (valores reajustados pelo IPCA para dezembro de 2018). Entre 2012 e 2018, ele fora $\mathrm{R} \$$ 59, mais de 2,5 vezes superior. O IPTU também teve igual movimento. Entre 2002 e 2008, o IPTU per capita médio era de R\$ 116 enquanto que entre 2013 e 2017 o indicador alcançou $\mathrm{R} \$ 168$ (50\% superior), chegando a R\$ 237 em 2018 (100\% superior).

Com relação a participação do ITBI na Receita Corrente Líquida, este teve participação média de 1,3\% entre 2002 e 2010, indicador que subiu para 1,9\% entre 2011 e 2018. A participação média do IPTU na Receita Corrente Líquida se manteve estável em 5,4\% entre 2002 e 2017. Porém em 2018 o indicador atingiu 7,2\% da Receita Corrente Líquida. Esses indicadores são mostrados nos Figuras 1, 2 e 3. 
Figura 1. IPTU e ITBI pelo PIB (em \%). Fonte: Siconfi/STN (2019).

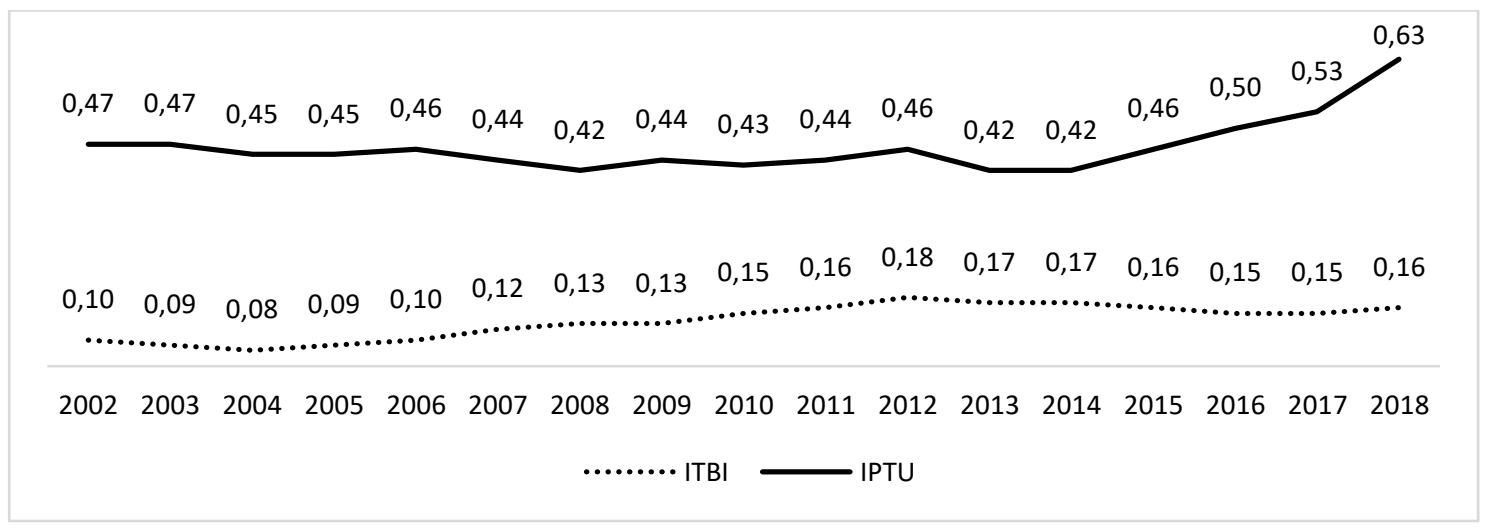

Figura 2. IPTU e ITBI per capita (em R\$ de Dez/2018). Fonte: Siconfi/STN (2019).

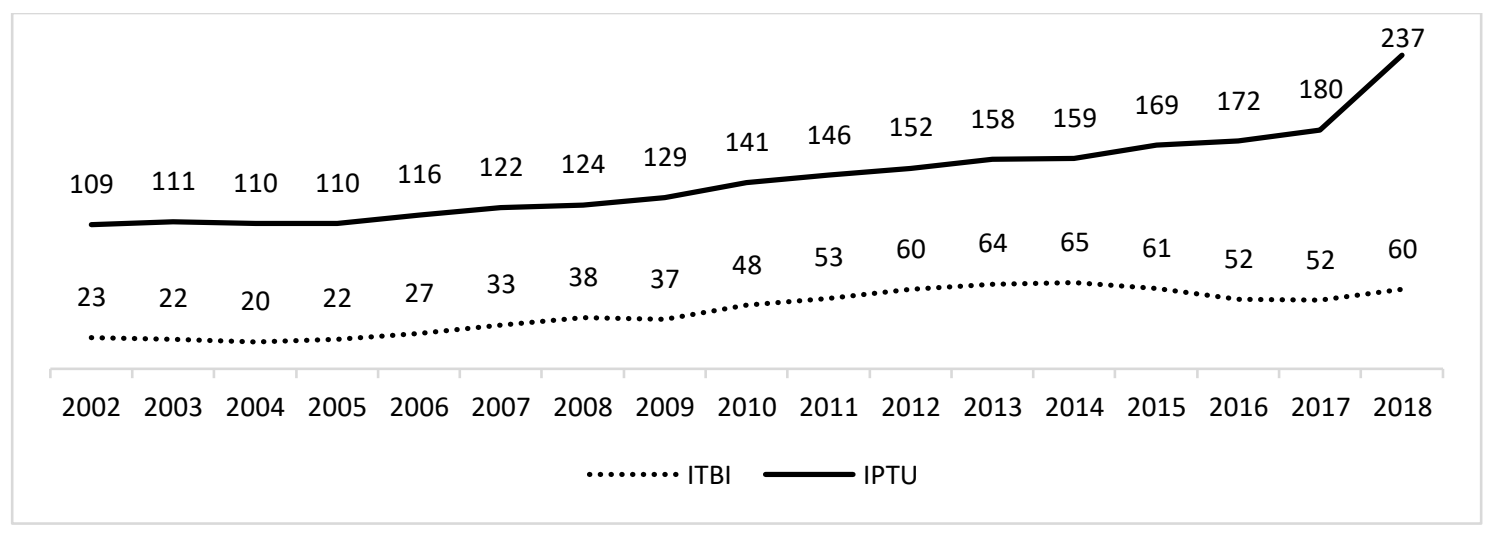

Figura 3. Participação do IPTU e do ITBI pela Receita Corrente (em \%). Fonte: Siconfi/STN (2019).

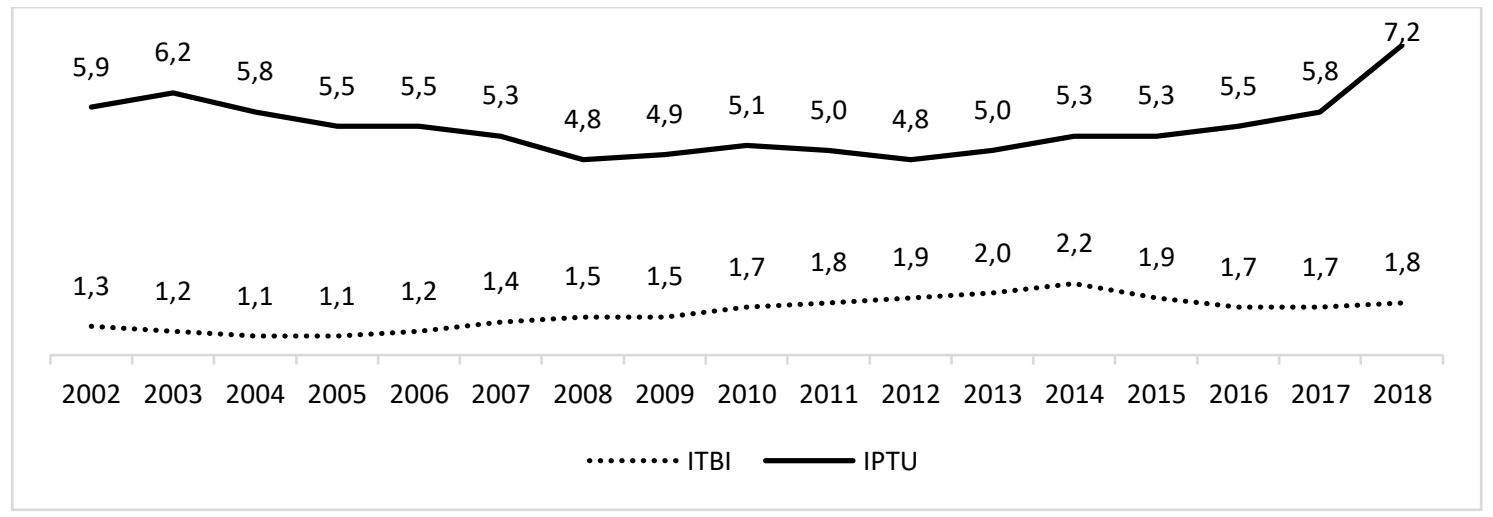

\section{ITBI Rural}

Apesar do aumente recente da arrecadação do IPTU nas grandes cidades brasileiras, a deficiência na administração do IPTU e o nível de inadimplência dos seus contribuintes ainda são elevados em municípios pequenos. Entre 2013 e 2016, em quase metade de todos os municípios brasileiros a arrecadação média do ITBI foi maior que a do IPTU (CARVALHO JUNIOR, 2017). Tal cenário é exacerbado nos estados mais rurais 
como em Rondônia, Tocantins, Maranhão, Alagoas, Paraná, Mato Grosso do Sul, Mato Grosso e Goiás aonde pelo menos $60 \%$ dos municípios em cada estado possuíram arrecadação do ITBI maior que a do IPTU neste período. Indo mais a fundo a arrecadação do ITBI é maior que a do IPTU em 85\% dos municípios do Estado do Tocantins e $77 \%$ do Estado do Mato Grosso. Tal fato pode corroborar a hipótese de que municípios pequenos e agrícolas tem pouca base imobiliária urbana, mais significativa base imobiliária rural e advogar para uma proposta de reforma tributária a nível nacional que transferisse a competência do ITR para os municípios, incluindo autonomia para elaborar a legislação do imposto, com integração das propriedades rurais à base de cálculo de um novo imposto imobiliário municipal mais abrangente. A partir da Emenda Constitucional no. 42 de 2003, apenas se permite que os municípios administrem o ITR seguindo a Lei Federal 9.393 de 1996, o que não torna possível um aumento efetivo da tributação. Isso porque a lei federal fixa as alíquotas com base no fator de utilização da terra e estabelece a auto declaração dos contribuintes do valor da terra nua, excluindose o valor das plantações e de quaisquer benfeitorias que nela se encontrem. Tal fato impede que os municípios tenham liberdade para determinar o valor de mercado da terra rural e a alíquota mais conveniente para arrecadar o imposto.

Mesmo em municípios com população acima de 200.000 habitantes, devido principalmente a desatualização da Planta de Valores e/ou inadimplência dos contribuintes, a média da arrecadação do ITBI foi maior que o IPTU em João Pessoa, Uberlândia, Petrolina, Ribeirão das Neves, Barueri, Arapiraca e Juazeiro. A Tabela 3 a seguir, mostra nesses 7 municípios: a) as arrecadações per capita do IPTU e do ITBI em 2015; b) o ano da última atualização da Planta Genérica de Valores; e c) o nível de inadimplência do IPTU no ano de 2012.

Tabela 3. Arrecadações per capita do IPTU e do ITBI, Ano da Última Atualização da Planta Genérica de Valores e Nível de Inadimplência do IPTU (Brasil, 7 municípios selecionados).

Fonte: Carvalho Junior (2017); IBGE (2017); Sisconfi/STN (2019).

\begin{tabular}{l|c|ccc}
\hline \multicolumn{1}{c|}{ Município } & $\begin{array}{c}\text { ITBI } \\
\text { Arrecadação }\end{array}$ & Arrecadação & IPTU & \\
\hline João Pessoa & 115 & 83 & 1972 & Inadimplência \\
Uberlândia & 81 & 78 & 1984 & $25 \%$ \\
Petrolina & 26 & 26 & 2013 & $40 \%$ \\
Ribeirão das Neves & 38 & 25 & 2008 & $40 \%$ \\
Barueri & 266 & 90 & 1989 & $10 \%$ \\
Arapiraca & 20 & 19 & 2012 & $74 \%$ \\
Juazeiro & 14 & 10 & 2014 & $89 \%$ \\
\hline
\end{tabular}

Conforme se observa na Tabela 3, as arrecadações do ITBI em João Pessoa, Uberlândia e Barueri foram maiores que as do IPTU principalmente porque as Plantas Genéricas de Valores estão defasadas nesses municípios, tendo sido atualizadas pela última vez nas décadas de 1970 e 1980 . Por outro lado, em Arapiraca e Juazeiro, uma taxa superior a 70\% de contribuintes inadimplentes com o IPTU, impede que o imposto tenha 
padrões mínimos de arrecadação. Em Ribeirão das Neves e Petrolina a inadimplência também é alta, arrecadando-se em média apenas $60 \%$ do IPTU lançado anualmente.

As maiores arrecadações do ITBI no Brasil (como percentual do PIB municipal ou da receita corrente) estão concentradas em municípios turísticos, devido ao grande número de transações imobiliárias comparado à baixa população residente, e em municípios centrados no agronegócio, devido ao grande número de transações rurais. A Tabela 4 mostra as 20 maiores participações do ITBI nas receitas correntes entre os municípios brasileiros (média entre 2013 e 2016)

Tabela 4. 20 maiores arrecadações municipais do ITBI (\% da Receita Corrente Líquida, média 2013-16). Fonte: Sisconfi/STN (2019)

\begin{tabular}{lccccl}
\hline Município & UF & População & $\begin{array}{c}\text { Área } \\
\left(\mathbf{e m ~} \mathbf{~ k m}^{\mathbf{2}}\right)\end{array}$ & ITBI & Característica \\
\hline Xangri-lá & RS & 13.951 & 61 & 12,5 & Veraneio \\
Itapema & SC & 55.016 & 59 & 9,3 & Turismo e Veraneio \\
Mara Rosa & GO & 10.320 & 1.703 & 9,1 & Agronegócio \\
Porto dos Gaúchos & MT & 5.361 & 7.012 & 8,7 & Agronegócio \\
Bombinhas & SC & 16.897 & 34 & 8,5 & Turismo e Veraneio \\
Extremoz & RN & 27.107 & 24 & 8,5 & Turismo e Veraneio \\
São Felix do Araguaia & MT & 11.039 & 16.848 & 8,3 & Agronegócio \\
Lagoa Santa & MG & 58.702 & 232 & 7,9 & Turismo e Veraneio \\
Aporé & GO & 4.043 & 2.900 & 7,6 & Agronegócio \\
Capão da Canoa & RS & 46.467 & 97 & 7,3 & Veraneio \\
Balneário Camboriú & SC & 124.557 & 46 & 7,2 & Turismo e Veraneio \\
Gramado & RS & 34.365 & 238 & 6,9 & Turismo e Veraneio \\
Bertioga & SP & 55.138 & 490 & 6,5 & Veraneio \\
Imbé & RS & 19.676 & 40 & 6,3 & Veraneio \\
Gaúcha do Norte & MT & 6.900 & 16.899 & 5,9 & Agronegócio \\
Santa Terezinha & MT & 7.798 & 6.451 & 5,9 & Agronegócio \\
Pium & TO & 7.264 & 10.013 & 5,7 & Agronegócio \\
Florianópolis & SC & 461.524 & 675 & 5,3 & Capital e Turismo \\
Valparaíso de Goiás & GO & 150.005 & 60 & 5,3 & Dormitório \\
Divinópolis do Tocantins & TO & 6.729 & 831 & 5,2 & Agronegócio \\
\hline
\end{tabular}

De acordo com a Tabela 4, dentre os 20 municípios com maior participação média do ITBI na Receita Corrente Líquida entre 2013 e 2016, 11 eram cidades turísticas ou de veraneio e 8 eram municípios com relevante setor do agronegócio. Esses últimos são municípios localizados sobretudo nos Estados do Tocantins, Goiás e Mato Grosso, com população pequena, mas área territorial extensa. Indo mais a fundo, entre os 100 municípios com maiores médias no período analisado, 43 estavam localizados na Região Centro-Oeste ou no Estado do Tocantins, o que demonstra que as transações de terras rurais nos cartórios desses municípios eram significativas. Em média, o ITBI representou ao redor de 5\% das receitas correntes desses 43 municípios. Isso mostra que além de ser usado como base de informações para a tributação imobiliária urbana pelo IPTU, o ITBI também pode ser usado na administração do ITR de forma a confrontar o valor da terra rural declarado 
pelo contribuinte e o valor médio das transações de mercado do município de sua localização (evidentemente, para isto deveriam ser celebrados convênios para troca de informações entre a Secretaria da Receita Federal, cartórios e prefeituras municipais). Além disso, os dados do ITBI também podem ser usados em possíveis estudos sobre o comércio e regulação de terras no Brasil, como a sua compra por pessoas jurídicas ou estrangeiros.

De qualquer maneira a administração tributária do ITBI é muito importante para estabelecer o nível de arrecadação e estudos de caso deveriam ser elaborados para se apontar as causas de sucesso ou fracasso na arrecadação do imposto. Por exemplo, a Tabela 4 mostra que o ITBI representou 9\% da Receita Corrente Líquida do Município de Mara Rosa no Estado de Goiás. No entanto, nos municípios limítrofes de Campinorte, Amaralina e Santa Terezinha de Goiás, todos com área ao redor de 1.200 quilômetros quadrados, o ITBI representou apenas $1 \%$ da Receita Corrente Líquida.

\section{CONSIDERAÇÕES FINAIS E RECOMENDAÇÕES DE POLÍTICA}

O texto mostrou que os tradicionais "Impostos sobre a Transferência Imobiliária" ou "Impostos do Selo", são amplamente utilizados em todo o mundo. Na maioria dos países, inclusive o Brasil, a sua base de cálculo é limitada apenas às transações imobiliárias. No entanto, em alguns países o imposto pode tributar também outros tipos de transferências patrimoniais como veículos, demais ativos mobiliários e até contratos financeiros e de arrendamento.

Quando o imposto não é aplicado somente sobre transferência imobiliária (embora costume ser a sua base tributária mais importante) sua arrecadação tende a ser muito maior. Em 2015, foi o caso da Coréia do Sul (2,14\% do PIB), da Austrália (1,37\% do PIB) e da Bélgica (0,95\% do PIB). Outros países, como Reino Unido, Portugal, Israel, Japão e Alemanha, conseguem uma arrecadação entre $0,3 \%$ e $0,5 \%$ do PIB tributando exclusivamente a transferência imobiliária, mas com alíquotas marginais superiores a $6 \%$.

O texto identificou que alíquotas progressivas, conforme o valor da transação imobiliária, são aplicadas por muitos países como Portugal, Hungria, Reino Unido, Israel, Irlanda, Austrália, África do Sul e Canadá. Inclusive, o artigo identificou que a Coréia do Sul, China e Canadá aplicam alíquotas majoradas como forma de se evitar a especulação imobiliária. O Brasil, por outro lado, tem arrecadado ao redor de 0,15\% do PIB, mediante alíquotas proporcionais do ITBI que variam entre $2 \%$ e $3 \%$, conforme o município.

Por volta de 2005, muitos municípios brasileiros, especialmente as maiores cidades, passaram a diferenciar o valor venal do IPTU e do ITBI. Tal fato foi importante para evitar a subdeclaração das transações imobiliárias, pois os valores de referência do ITBI são baseados em pesquisas de mercado enquanto os valores 
venais do IPTU costumam ser muito defasados. Tal modelo evita a evasão do próprio imposto e do Imposto de Renda sobre Ganhos de Capital.

Há ainda uma tendência recente entre os municípios, principalmente a partir de 2012, e por motivos fiscais, da majoração das alíquotas do ITBI de $2 \%$ para $3 \%$. Não obstante, a progressividade do imposto está vedada pela Súmula 656/2011 do Supremo Tribunal Federal. O próprio STF, por outro lado, sofreu mudanças na sua composição e passou a validar a progressividade fiscal de outros impostos, como o IPTU e o ITCM. Por isso, nada impede que a progressividade do ITBI possa ser revista, ainda mais se houver permissão constitucional para isso. Com base na experiência internacional, um sistema de alíquotas progressivas do ITBI entre $2 \%$ e $8 \%$ poderia ser perfeitamente aplicável no Brasil sem impacto significativo no mercado imobiliário, e ao mesmo tempo, aumentando-se a justiça fiscal, que é a principal demanda de uma reforma tributária no Brasil.

O estudo também verificou que o ITBI rural é uma fonte de receitas muito importante em municípios com relevante setor de agronegócios na Região Centro-Oeste e no Estado do Tocantins, mostrando um cenário de elevado número de transações de terras rurais bem como de aumento de seu valor de mercado. Tal fato, merece atenção especial e iniciativas de pesquisas futuras nesse tema, como estudos de casos, seria bastante relevante. Além disso, esse cenário mostra que municípios pequenos com pouca base imobiliária urbana poderiam ser beneficiados com uma reforma tributária em que as propriedades rurais fossem incorporadas ao sistema de tributação imobiliária municipal com finalidade fiscal (a União poderia continuar com a competência sobre o ITR para fins regulatórios).

A exemplo do que ocorre em diversos países, uma outra proposta a ser aplicada numa reforma tributária seria a ampliação da base de cálculo do ITBI para outras transferências e registro de bens reais, como veículos e aluguéis de imóveis. A base de cálculo do registro ou da transferência de proprietário de veículos automotores poderia ser o valor da Tabela Fipe utilizada no IPVA, mas a alíquota deve ser definida nacionalmente devido a mobilidade da base de cálculo. No caso dos aluguéis, a base de cálculo, a exemplo do que ocorre em outros países, deve ser o somatório de todos os aluguéis previstos no contrato. Evidentemente, um limite de isenção deve ser aplicado para se evitar um perfil regressivo ao ITBI, a ser aplicado sobre automóveis ou alugueis residenciais de baixos valores. Apesar de em muitos países o imposto ainda englobar a transferência e o registro da propriedade financeira, para o caso do Brasil, entende-se que essa deva ser uma prerrogativa do governo federal, como ocorreu com a CPMF, e os ativos financeiros não deveriam estar sujeitos ao ITBI municipal.

Resumindo-se, as principais propostas para o debate de uma reforma do ITBI que este estudo levantou, passam por três principais pontos: 
a) Ampliação da base de cálculo do ITBI para outros tipos de atos e contratos relativos à ativos reais, como a transferência (mas também o primeiro registro) de bens móveis (automóveis por exemplo) e contratos de arrendamento e aluguel;

b) Previsão constitucional para a progressividade das alíquotas do ITBI, com a delimitação nacional de um intervalo de variação, recomendando-se que seja entre $2 \%$ e $8 \%$, com um limite de isenção para pequenos aluguéis residenciais, transferências imobiliárias e automóveis. Além disso, a exemplo do que ocorre na Coréia do Sul, China e recentemente no Canadá, o Senado Federal poderia autorizar o aumento desse intervalo para algumas cidades, por exemplo para até $15 \%$, como forma de se mitigar o crescimento de bolhas imobiliárias;

c) Concessão de apoio e financiamento às administrações tributárias municipais de forma que elas possam cobrar o ITBI de maneira mais eficiente. Por exemplo, o convênio com os cartórios e o estabelecimento de valores de referência do ITBI deveria ser incentivado. Estes valores de referência devem ser sempre estabelecidos por decreto municipal, como forma de aumentar a sua transparência.

Por fim, o artigo mostrou que apesar de ser pouco debatido e de certo forma negligenciado nos debates de reforma tributária, o ITBI tem funções importantes, muito além de fiscais, tendo um papel a cumprir no sistema tributário brasileiro.

\section{REFERÊNCIAS}

Antunes, T. R. Imposto sobre Transmissão de Bens Imóveis Inter Vivos: aspectos gerais, suas imunidades, isenções e não incidência, 2012 (mimeo). https://goo.gl/LvqqNK

Aregger, N.; Brown, M.; Rossi, E. Transaction Taxes, Capital Gains Taxes and House Prices, Swiss National Bank, 2013 (Working Paper). https://goo.gl/764Xye

Berárd, G; Trannoy, A. The Impact of a Rise in the Real Estate Transfer Taxes on the French Housing Market. AMSE (Aix Marseille Scholl of Economics) (Working Paper Nr 32/2017), 2017. https://goo.gl/eyWhxN

Besley, T.; Meads, N.; Surico, P. The Incidence of Transaction Taxes: Evidence from a Stamp Duties Holiday. Journal of Public Economics, 119, 61-70, 2014.

Best, M. C.; Kleven, H. J. Housing Market Responses to Transactions Taxes: Evidence from Notches and Stimulus in the UK (Working Paper), 2016

Carvalho Junior, P. H. B. Property Tax Performance and Potential in Brazil. (Tese de Doutorado). Pretoria, África do Sul, Universidade de Pretória, 2017. https://goo.gl/Ddv6KS

Comunidade da Austrália. Stamp duty, 2016. https://goo.gl/Etmeod

Crowe, C.; Dell'Ariccia, G.; Igan, D. How to Deal with Real Estate Booms: Lessons from Country Experiences, FMI, Working Paper, WP/11/91, 2001 
Dachis, B.; Duranton, G.; Turner, M. A. The Effects of Land Transfer Taxes on Real Estates Market: Evidence from a Natural Experiment in Toronto. Journal of Economics Geography, 12(2), 327-354, 2012..

Davidoff, I.; Leigh, A. How Do Stamp Duties Affect the Housing Market? Economic Record, 89(286), 396-410, 2013.

DLA PIPER. Real Estate Investment in France: The Legal Perspective, 2017. https://goo.gl/SNzUGt

DTTL (Deloitte Touche Tohmatsu Limited). Taxation and Investment in Korea 2016: Reach, relevance and reliability. Delloite, 2016. https://goo.gl/7DkMkA

Fisconetplus. Fiscal Discipline: Registration taxes, mortgage dues and court fees, 2017. https://goo.gl/saMqJs

FMI (Fundo Monetário Internacional). Government Finance Statistics: Manual 2014. FMI, 2014. https://goo.gl/JWXbFq

IBGE (Instituto Brasileiro de Geografia e Estatística). Perfil dos Municípios Brasileiros Esporte - 2016, IBGE, 2017.

GPG (Global Property Guide). Roundtrip costs are moderate to high in Germany, 2017. https://goo.gl/wo8AWS

Harada, K. Imposto sobre transmissão de bens imóveis (ITBI). Revista Jus Navigandi 5(40), 2000. https://jus.com.br/artigos/1400.

JLL (Jones Lang La Salle Property Consultants). Taxes on acquisition and transfer of real estate, 2017. https://goo.gl/rvL4iZ

KPMG. Acquisition of residential properties in Switzerland, 2016. https://goo.gl/9q9DYT

KPMG. Tax Profiles (vários países), 2017. https://goo.gl/YYv2ce

Lee, D. J. Y; Kim, K. D. South Korea: Overview of the Stamp Duty Regime. Pricewaterhouse Coopers, 2007

Man, J. Y. China's Property Tax Reform: Progress and Challenges. Land Lines April 2012. Lincoln Institute of Land Policy, 2012. https://goo.gl/nyTNvA

NCSL (National Conference of State Legislatures). Real Estate Transfer Taxes, 2016. http://www.ncsl.org/research/fiscal-policy/realestate-transfer-taxes.aspx

OCDE (Organização para a Cooperação e Desenvolvimento Económico). The OECD classification of taxes and interpretative guide, In OCDE, Revenue Statistics: 1965-2016, OECD Publishing, 2017. https://goo.gl/hiqivk

PWC (PricewaterhouseCoopers). Overview of the German Real Estate Transfer Tax rates, 2016. https://goo.gl/LcxPMP

Reino Unido da Grã-Bretanha e Irlanda do Norte. Stamp Duty Land Tax, 2017. https://www.gov.uk/stamp-duty-land-tax

RENX (Real Estate News Exchange). Calculating land transfer taxes across Canada, 2015. https://renx.ca/calculating-land-transfertaxes-across-canada/

República Portuguesa. Código do Imposto Municipal Sobre as Transmissões Onerosas de Imóveis, 2017. https://goo.gl/vu5ntD

SARS (South African Revenue Service). Transfer Duty, 2017. https://goo.gl/QhoZ2P

Shanda, X.; Daoshu W. Land and Property Tax in China. In: Bird, L. M; Slack, E. Land Taxation in Practice: Selected Studies. Toronto, The World Bank, 2002. https://goo.gl/E7GXks

Silva, T. M. P. O ITBI e as operações financiadas pelo Sistema Financeiro da Habitação. Revista Jus Navigandi 15(2725), 2010. https://jus.com.br/artigos/18067

Smolka, M.O. 2013. Implementing Value Capture in Latin America: Policies and Tools for Urban Development. Cambridge: Lincoln Institute of Land Policy, Policy Focus Report. https://goo.gl/I5nJGs

Sisconfi/STN. 2019. Sistema de Informações Contábeis e Fiscais do Setor Público Brasileiro (Siconfi). Brasília, STN.

UN-Habitat (United Nations Human Settlements Program). Property tax regimes in Europe. Nairobi, UN-Habitat, 2013 (Principal autor: R.R. Almy). 